\title{
Analysis and Design of Implementation of Class F Airspace in the Czech Republic
}

\author{
Filip Črvený \\ Department of Air Transport \\ Department of Air Transport, Faculty of Transportation \\ Sciences, Czech Technical University \\ Horská 3, Praha 2, 128 03, Czech Republic
}

\author{
Jakub Kraus \\ ATM Systems Laboratory, \\ Department of Air Transport, Faculty of Transportation \\ Sciences, Czech Technical University \\ Horská 3, Praha 2, 128 03, Czech Republic \\ e-mail: kraus@fd.cvut.cz
}

\begin{abstract}
Czech Republic and suggests the implementation of class $F$ airspace in the Czech Republic for IFR flights at uncontrolled aerodromes. It also suggests procedures and technologies for increasing of safety when performing IFR flights at these aerodromes in class $F$ airspace.
\end{abstract}

Keywords: Airspace, radar coverage, AFIS, airspace class $F$, multilateration, ADS-B, SERA

\section{INTRODUCTION}

Currently, IFR flights in the Czech Republic can be performed only at controlled aerodromes and that significantly limits the traffic at uncontrolled ones during poor weather conditions. The minimum flight visibility specified for VFR flight is 1500 meters, but for IFR flight it is possible to land with zero visibility, provided that it is allowed by aerodrome equipment, aircraft equipment and crew has appropriate training. There is no need to wait for the improvement of weather conditions, which increases the number of possible flights and it may affect the expansion of the airlines and the aerodrome infrastructure. There are many countries, where is possible to conduct IFR flights from uncontrolled aerodromes. They use different methods for the purposes of this traffic. One suitable solution is the implementation of class $\mathrm{F}$ airspace.

The aim of this article is to analyse the aviation regulations, the airspace organization of the Czech Republic and to assess the current technological possibilities for the introduction of class $\mathrm{F}$ airspace. Another task is to analyse the properties of class $\mathrm{F}$ airspace and to consider the rules and procedures in this type of airspace. The Federal Republic of Germany has been using this solution for the operating of IFR flights at uncontrolled aerodromes successfully for many years and therefore it's useful to analyse and evaluate the Germany's procedures.

Based on these analyses, the aim is to create a design of class $\mathrm{F}$ airspace in the Czech Republic. In addition to the shape and boundaries of the class $\mathrm{F}$ airspace, it is also important to design appropriate procedures and to suggest technologies which can increase the safety. It is appropriate to evaluate the feasibility of these proposals with regard to other solutions.

\section{AIRSPACE OF THE CZECH REPUBLIC}

\section{A. Classfication of airspace}

Airspace classes C, D, E and G are currently used in the Czech Republic. Moreover, there are created Aerodrome Traffic Zones (ATZ) around the uncontrolled aerodromes. ATZs extend from the ground level up to 4000 feet AMSL within the circuit of radius $3 \mathrm{NM}$ centred in the aerodrome reference point.

VMC minima in class $\mathrm{G}$ are visibility $5 \mathrm{~km}$, clear of clouds and terrain surface in sight. It can be decreased to $1.5 \mathrm{~km}$, if conditions allow. VMC minima in class $\mathrm{E}$ are visibility $5 \mathrm{~km}$ below FL100, 1000ft vertically and $1500 \mathrm{~m}$ horizontally from clouds. Above FL100, the visibility is increased to $8 \mathrm{~km}$.

\section{B. Mandatory equipment}

It's mandatory for all IFR flights in FIR Prague to be equipped with mode $S$ Elementary Surveillance transponders. VFR flights outside of CTR Ruzyne and TMA Prague GNDFL60 (5000ft) are not required to be equipped with transponders.

\section{Radar coverage of the Czech Republic}

The coverage of the Czech Republic is provided by primary surveillance radars, secondary surveillance radars and passive radar systems which are deployed on the territory of the Czech Republic, while also using data from radars of neighbouring countries. There are TAR Prague, TAR Brno and TAR Ostrava and their coverage is guaranteed above FL85. There are also secondary surveillance radars MSSR Prague, MSSR Buchtuv kopec and MSSR Pisek. Their coverage is guaranteed in CTA Prague, CTA Ostrava and CTA Brno above $5000 \mathrm{ft}$ AMSL. There are three Wide Area Multilateration systems. WAM Prague, Brno and Ostrava. Their average coverage is 80NM.

\section{AFIS}

Aerodrome with AFIS is defined as follows: The aerodrome with AFIS is an uncontrolled aerodrome, about which was decided that there will be provided an Aerodrome Flight Information Service and emergency service to known 
traffic. There must be an agreement on mutual cooperation and coordination between adjacent stations. In such cases, it's the AFIS responsibility to provide flight information service and alerting service to aircraft in adjacent or overlapping areas. The chief executive officer of AFIS unit is responsible for the administration of this Agreement and its contents. Aerodromes Hradec Kralove, Mnichovo Hradiste, Pribram and Ceske Budejovice were selected as appropriate for providing IFR flights at uncontrolled aerodromes.

\section{ClaSS F AIRSPACE}

In this type of airspace, it is possible to operate IFR and VFR flights. The flight information service is provided to both type of flights and there is traffic advisory service provided to IFR flights. The flights in this area are not subject to the ATC clearance. IFR flights must still maintain two-way radio communication in this area, while this is not required for VFR flights. The maximum speed for all flights is $250 \mathrm{kt}$ IAS below FL 100. The traffic advisory service should serve as a transitional measure until substituted by air traffic control. The maximum time interval has not been established until now, so it was possible to use this airspace effectively for IFR flight operations at uncontrolled aerodromes for an unspecified period of time. There will be applied new rules in the future, which are mentioned in the fifth chapter of this article. The introduction of this type of airspace doesn't need to limit the operation throughout the FIR, but only in the vicinity of uncontrolled aerodromes at which IFR flights are performed.

\section{A. Air traffic advisory service}

This service should be introduced where it is not possible to provide air traffic control and information provided by flight information service is not sufficient. However, as already noted, this service should be considered as a temporary measure and should be eventually replaced by the air traffic control service. The air traffic advisory service aims to improve air traffic safety in the area of class $\mathrm{F}$ and especially by comparison with flight information service provides more effective information about the possible dangers and risk of collision. Nevertheless, this service does not provide such safety as the air traffic control service. In some cases, air traffic advisory service can have incomplete information about the flight operations in the class F airspace, and therefore information for avoiding collisions may not always be correct. The air traffic advisory service is provided to IFR flights in the airspace class $F$ that request it or where it's required by the local procedures. The operator of this station therefore uses the words "suggest" and "recommend" in the event of any instructions given to the aircraft. The pilot must decide whether to adapt to the suggestion or recommendation, and he must inform the provider of this service about his intentions.

\section{B. Flight Information Service}

The commander of an aircraft has the ultimate responsibility for decisions on any proposed changes in the flight plan. Flight Information Service is provided to all aircraft under air traffic control service, other known air traffic services and to aircraft, which can benefit from information provided by flight information service. The air traffic control service has priority over the flight information service. The flight information service shall provide information about reported or forecasted meteorological conditions at the aerodrome of departure, destination and alternates.

\section{The procedures and regulations of the Federal Republic of Germany to ensure safety in class $F$ airspace}

This operation principle of IFR flights at uncontrolled aerodromes has been working in the Federal Republic of Germany successfully since April 28, 1994, when it was introduced at the aerodrome Schwäbisch-Hall. It has been successfully working for twenty years. In the Federal Republic of Germany, the uncontrolled class $\mathrm{G}$ airspace is in the range GND - $2500 \mathrm{ft}$ AGL and IFR flights are prohibited here. In order to allow IFR arrivals and departures to/from uncontrolled aerodromes, there is introduced temporary uncontrolled class $\mathrm{F}$ airspace with higher minima for VFR flights in the vicinity of these aerodromes. The activation time of this space is indicated by the abbreviation $\mathrm{HX}$, which means that the operating time is not specified. The information regarding to the activation of this airspace can be obtained from stations providing the flight information service and the air traffic control service. It is the duty of flights, which intend to operate in airspace class F, to obtain information about its activation. VFR flights are not required to obtain permission.

The airspace class $\mathrm{F}$ is composed of two parts. The first part is a block area around the runway with vertical boundary GND - $2500 \mathrm{ft}$ AGL and a horizontal range of $7 \mathrm{NM}$ lengthwise and 3 NM crosswise from the runway threshold. The second area consists of two arcs with a radius of $10 \mathrm{NM}$ set at each side against each other in the axis of departure and arrival. This partial area has a vertical range $1500 \mathrm{ft}-2500 \mathrm{ft}$ AGL and forms the outer borders of the two partial areas. The separation between IFR flights in class F is ensured by the fact that only one IFR flight is permitted to enter at the same time. The spacing between IFR and VFR flights is not ensured. The commanders are responsible for it.

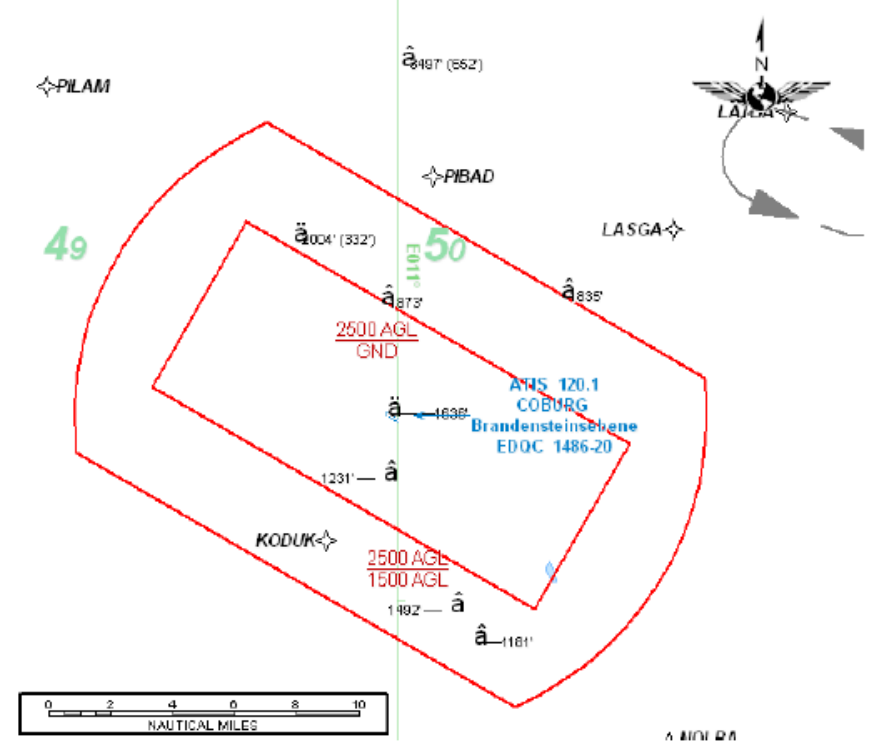

Figure 1. Class F airspace at Brandensteinsebene aerodrome [13] 


\section{THE DESIGN OF PROCEDURES FOR ClASS F AIRSPACE}

Based on previous analyses of the airspace of the Czech Republic and IFR flight procedures, it is appropriate that class $F$ airspace should be defined by distance of 7 NM longitudinally from each threshold and 3 NM laterally to each side. Proposed vertical range is GND - 1,000 feet AGL, so as to introduce airspace class F instead of airspace class G. ATZ of this uncontrolled IFR aerodrome will remain, there will be only change in the distribution of airspaces contained in it, when airspace class $F$ replaces the airspace class $G$. The same rules would be effective for the surroundings of ATZ, which will interfere into this airspace.

It is necessary to adjust IFR procedures at these aerodromes not only with the reference to the terrain around the aerodrome, but also the layout of this airspace. In some cases, the airspace class F can interfere with TMAs or CTRs and it will be necessary to make adjustments to the local area. The designed airspace allows only a circling approach for aircraft category A and $\mathrm{B}$. If it is necessary to establish procedures for the circling of aircraft categories $\mathrm{C}$ and $\mathrm{D}$, it would be necessary to extend the dimensions of proposed airspace.

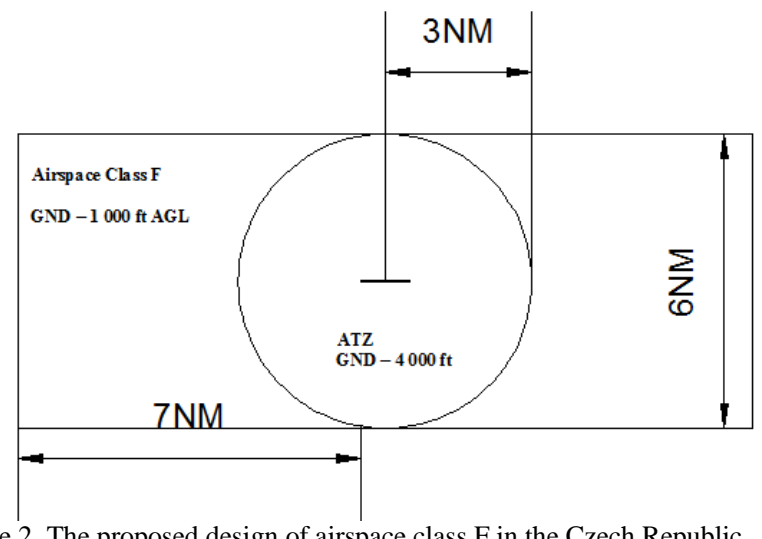

Figure 2. The proposed design of airspace class $\mathrm{F}$ in the Czech Republic

Primary and secondary radar systems are being replaced by more economical alternative tracking systems such as multilateration systems and ADS-B receivers. These systems appear to be effective and economically feasible option for increasing the safety around these uncontrolled IFR aerodromes, including avoiding collisions and air traffic flow management. The output of these systems could be displayed to AFIS officer and to the air traffic advisory services.

With the introduction of class $\mathrm{F}$ airspace it is also necessary to provide changes to the current rules and procedures or implement new ones in order to maintain the required level of safety of flight operations.

It seems the best to operate this airspace as HX, i.e. with operating time not specified. AFIS officer in agreement with the ATC will announce the activation of airspace class F in case of departure or arrival of an IFR flight. Both stations will provide information about the activation or deactivation to all aircrafts on the frequency affected by the new situation.

The newly established minimum requirements for VMC in airspace class F should be:

\section{- $5 \mathrm{~km}$ flight visibility}

- Horizontal distance from clouds: $1500 \mathrm{~m}$

- Vertical distance from clouds: $1000 \mathrm{ft}$

If a VFR flight will be located in a deactivated class $F$ airspace, when meeting the conditions for flight in class $G$ airspace and subsequently the airspace class $\mathrm{F}$ is activated, and the VFR flight is no longer able to fulfil the conditions for flight in this area, it must immediately leave this airspace. After this traffic leaves, the IFR flight may be allowed into this space. Mandatory continuous two-way radio communications in the airspace class $\mathrm{F}$ will improve coordination and provide greater prevention of collisions.

\section{THE ASSESMENT OF THE IMPLEMENTATION}

As part of the assessment, the airspace Class $F$ was compared with other solutions for the implementation of IFR operations at uncontrolled aerodromes. This analysis revealed that class $\mathrm{F}$ airspace is very simple solution with acceptable level of safety for introduction of IFR operations against operations in class $\mathrm{G}$, or introduction of new type of airspaces, such as TIZ, RMZ, TMZ.

There were also analysed the new Standardizes European Rules of the Air (SERA), which will become effective in the Czech Republic at the end of 2014. These regulations determine the maximum time period for established class $F$ airspace to three years. These regulations tend to prefer IFR operations at uncontrolled aerodromes within Class $\mathrm{G}$ airspace with the creation of RMZ and TMZ around these aerodromes. Thanks to definitions of RMZ a TMZ in SERA, the introduction of these airspaces will be also very simple. There is unfortunately one disadvantage that RMZ has higher requirements for aircraft equipment - mandatory radio.

The designed class $\mathrm{F}$ airspace may still serve as appropriate transitional measure for IFR operations at uncontrolled aerodromes before appropriate legislative changes will be made for the SERA.

\section{CONCLUSION}

The analysis of the rules and procedures in the Czech Republic showed that it is possible to apply the solution of the class $\mathrm{F}$ airspace for IFR flights at uncontrolled aerodromes. There are also affordable, economically accessible technologies that can contribute to increase of safety, without the need for costly investments to transform these aerodromes to controlled ones. There were also analysed properties and methods of class $\mathrm{F}$ airspace and specific procedures and rules in the Federal Republic of Germany where has been class F airspace successfully used for twenty years.

Based on these analyses and the assessment of IFR flight procedures, there was created a design of class $F$ airspace in the Czech Republic applied for IFR flights at uncontrolled aerodromes. The designed airspace class $F$ protects IFR flights from the traffic in Class $G$ airspace, thereby increasing the safety of flight operations. 
The feasibility of this changed airspace of the Czech Republic and its aspects were evaluated. The created airspace class F was compared with alternative solutions. It's possible to say that airspace class $F$ offers a cost-effective solution that provides increased safety than other solutions. And therefore, it is possible to apply it for IFR flight operations at uncontrolled aerodromes in the Czech Republic.

At the end of 2014, new Standardized European Rules of the Air will be applied in the Czech Republic. These rules plan to limit establishment of class $\mathrm{F}$ airspace only for a temporary period of three years and at the same time introduce RMZ and TMZ that tightens requirements for aircraft equipment. The airspace class $\mathrm{F}$ is a suitable solution for a temporary form of airspace. At the time of its integration into the airspace, it is possible to equip airplanes and aerodromes with new technologies to meet the requirements of the new rules and make legislative changes due to European regulations.

\section{REFERENCES}

[1] Ministerstvo dopravy České republiky. Letecký předpis L11, Letové provozní služby. Praha: Letecká informační služba Rízení letového provozu České republiky, 2013.

[2] Ministerstvo dopravy České republiky. Letecký předpis L2, Pravidla létání. Praha : Letecká informační služba Řizení letového provozu České republiky, 2013.

[3] AIP CR [online]. Available at <http://ais.ans.cz/ais_data/www_main_control/frm_cz_aip.htm>

[4] EUROCONTROL. EAD Basic. [online]. [cit. 2014-04-05]. Available at: <https://www.ead.eurocontrol.int/publicuser/public/pu/login.jsp>

[5] European Commission. Commission Regulation (EU) No 965/2012. [online]. Available at: <http://eurlex.europa.eu/LexUriServ/LexUriServ.do?uri=OJ:L:2012:296:0001:014 8:EN:PDF>

[6] Luftfahrthandbuch Deutschland. AIP Germany Frankfurt: DFS Deutsche Flugsicherung GmbH, 2014.

[7] Ministerstvo dopravy České republiky. Letecký předpis L8168, Provoz letadel - letové postupy. Praha: Letecká informační služba Řizení letového provozu České republiky, 2010.

[8] International Civil Aviation Organization. Aircraft Operations, Volume II, Construction of Visual and Instrument Flight Procedures. Montréal : Document Sales Unit, 2006.

[9] European Commission. Commission Implementing Regulation (EU) No 923/2012. Brusel: Publications Office, 2012.

[10] European Aviation Safety Agency. Acceptable Means of Compliance and Guidance Material to the rules of the air. Köln: European Aviation Safety Agency, 2013.

[11] European Aviation Safety Agency . Notice of proposed amendment (NPA) No 2011-02 . Köln: European Aviation Safety Agency, 2011.

[12] European Aviation Safety Agency. Notice of proposed amendment (NPA) No 2012-14. Köln: European Aviation Safety Agency, 2012.

[13] Jeppesen-Sanderson. Jeppview for Windows. [software] 2014. System requirements: Microsoft Windows XP SP2, Vista, Windows 7, $1 \mathrm{Ghz}, 1$ GB RAM, $32 \mathrm{MB}$ video card, Broadband Internet connection, disk space $2,15 \mathrm{~GB}$. 